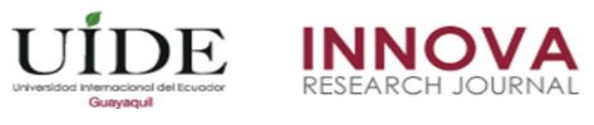

INNOVA Research Journal, ISSN 2477-9024

(Abril, 2018). Vol. 3, No.4 pp. 44-56

DOI: https://doi.org/10.33890/innova.v3.n4.2018.476

URL: http://revistas.uide.edu.ec/index.php/innova/index

Correo: innova@uide.edu.ec

\title{
Developing awareness of unknown sounds to improve merging and substitution pronunciation mistakes
}

\section{Desarrollo de la conciencia de los sonidos desconocidos para mejorar la fusión y la sustitución errores de pronunciación}

\author{
Evelyn Almeida \\ Diana Castillo \\ Soledad Parra \\ Universidad Central del Ecuador, Ecuador \\ Universidad de las Fuerzas Armadas ESPE, Ecuador
}

Autor corresponsal: evalmeida@uce.edu.ec,dacastillo@uce.edu.ec,dsparra@uce.edu.ec Fecha de recepción: 26 de Septiembre de 2017 - Fecha de aceptación: 15 de Abril de 2018

Resumen: A pesar de que el énfasis en la enseñanza de la pronunciación de un segundo idioma ha sido casi nulo entre los educadores e investigadores de EFL, estudios recientes muestran la pronunciación como un factor clave para aprender un segundo idioma. Este artículo revisa la literatura de expertos en el campo que destacan la relevancia de la enseñanza de la pronunciación. Con el fin de proporcionar a los lectores una base teórica, el documento presenta primero una revisión de las discusiones recientes sobre la necesidad de enseñar la pronunciación. Luego ofrece una descripción de las características de la pronunciación, factores influyentes, problemas como la fusión y la sustitución causada por las diferencias entre el sistema fonológico del Primer y Segundo Lenguaje y las metodologías de enseñanza. Dentro de este contexto, hemos favorecido uno de los enfoques que arrojan luz sobre el desarrollo de la conciencia de la pronunciación. Finalmente, se proponen algunas actividades que tienen como objetivo ayudar a los estudiantes a pronunciar sonidos desconocidos de una manera clara e inteligible.

Palabras Claves: pronunciación; conciencia fonológica; errores de fusión; sustitución

\begin{abstract}
Although emphasis on teaching pronunciation of a second language has been almost null among EFL educators and researchers, recent studies portray pronunciation as a key factor to learn a second language. This paper reviews literature of experts on the field who highlight the relevance of teaching pronunciation. In order to provide the readers with a theoretical basis the paper first presents a review of recent discussions on the necessity to teach pronunciation. Then it offers a description of the features of pronunciation, influential factors, problems such as merging and substitution caused by the differences between the First and Second Language phonological system, and teaching methodologies. Out of this context, we have favored one of the approaches which shed light on the development of pronunciation awareness. Finally some activities which aim to help learners pronounce unknown sounds in a clear and intelligible way are proposed.
\end{abstract}

Key Words: pronunciation; phonological awareness; merging; substitution mistakes 


\section{Introducción}

English is one of the most spoken languages around the world. Millions of people use this language as their mother tongue, their second or their foreign language. Regarding Ecuador, even though Spanish is the mother tongue, the need to learn English and have effective communication skills in this language is imposed, like in most countries, mainly by business opportunities, the educational system requirements, the possibility of traveling or studying abroad, the social demands such as cultural expectations and globalization. (Marginson \& van der Wende, 2006)

Research about learning pronunciation in a second language or foreign language has been very limited until the beginning of the 21 st century. As Derwing and Munro (2005) mentioned, pronunciation had become a casualty of Communicative Language Teaching before this century. This approach gives emphasis to the meaning of a word and pays little attention to pronunciation, under the belief that exposure will improve pronunciation. However, after 2005, several L2 pronunciation studies have appeared in the literature, especially in theses or conference papers. For instance, we can refer to the annual conference Pronunciation in Second Language Learning and Teaching or the new Journal of Second Language Pronunciation. These latest initiatives have placed L2 pronunciation as an area worthy of investigation.

Celce-Murcia, Brinton, \& Goodwin (1996) established that pronunciation is the foundation of speaking. Furthermore, they claim that the most important part of learning a second language "rests on pronunciation" since it allows students to express their ideas and have effective communication with native speakers (p. 23). Unfortunately, in Ecuador the importance of teaching pronunciation is ignored by a large number of teachers who prefer to pay more attention to grammar or vocabulary, somehow ignoring the fact that in everyday spoken language, the most important thing to be considered is appropriate pronunciation.

The process of learning pronunciation can be affected by many factors like age, motivation, methods and quality of teaching, as well as the influence of the learner's mother tongue (Celce-Murcia, Brinton, \& Goodwin, 1996). Regarding the learner's language, if the sounds or phonemes of the mother tongue are similar to the ones on the target language, it becomes an advantage when learning pronunciation, but the non-existence of particular English sounds in the mother tongue has proved to be a problem for the students. For instance, according to Tritch (2016), learners face merging problems when they pronounce the new sounds in terms of the speech sounds of their mother tongue or substitution problems when the learners wrongly substitute a new sound with the most similar sound they know. Tritch (2016) remarks that merging and substitution can cause serious problems of intelligibility and communication breakdowns. The definitions of merging and substitution proposed by Tritch are used in the current research to understand and analyze some common pronunciation problems made by learners.

The interest for reviewing this topic occurred because on a regular basis, teachers face learners who have a good knowledge of grammar structures and vocabulary, but perform very poorly on speaking mainly because of their pronunciation. The aim of this paper is to provide teachers a theoretical background about the relevance of teaching pronunciation and offer some 
tools to help students overcome the pronunciation problems caused by merging or substitution problems.

\section{Literature review}

Since the aim of this paper is to improve the pronunciation of L2 Learners, it is necessary to define the word pronunciation. According to Burns \& Claire (2003), "pronunciation refers to the phonology of the language or the meaningful perception and production of the sounds of that language and how they impact on the listener" ( p. 5). In fact, the way people articulate sounds can mark the social class of the speaker, their education, age, and other social aspects (Macháčková, Bc., 2012).

As Celce-Murcia, Brinton, and Goodwin (2010) established, most EFL teachers' goal is for their students to have good pronunciation or native-like pronunciation, but "there are so many varieties of English and so much variation within each type that it is almost impossible to define the ideal pronunciation". The authors also added that a more realistic goal currently recommended is intelligible pronunciation, which means being understood by native and nonnative speakers with minimal effort. A similar idea proposed by Tritch (2016) is that the goal should be to achieve accurate pronunciation that allows students to have a fluent conversation (p.2).

Poor pronunciation can make communication difficult not just for the learner who might feel frustrated, but also for the listener who will find it difficult to follow the conversation (Celce-Murcia, Brinton \& Goodwin, 1996). Russell (2016) established that pronunciation requires habit formation, which implies constant repetition. In order to hear a "strange" sound, our brain needs to form new connections that will allow it to recognize these sounds. Tritch (2016) added that in this process of recognizing new sounds in the target language, at the beginning, the adult students are literally unable to hear the sounds which are entirely strange to them. The author strongly suggested that teachers provide students with activities that help them recognize and produce the unknown sounds. From all of the above, it is clear that mastering pronunciation requires much practice and repetition, and that teachers should explicitly help their students to achieve adequate pronunciation in the target language.

\section{Pronunciation features}

To understand pronunciation better, it is necessary to analyze the features of pronunciation. According to Ramelan (1994), there are 2 primary features of pronunciation:

1. Segmental features, or just segmental, which refer to sound units arranged in a sequential order, e.g.: vowels, consonants, diphthongs.

2. Supra-segmental features, or just supra-segmental, such as stress, pitch, length, intonation, and other features that always accompany the production of segmental.

Although the segmental and the supra-segmental features are both important aspects of pronunciation, it is necessary to mention that the activities proposed in this paper to practice 
pronunciation were focused mainly on improving the pronunciation of the segmental features of the phonemes $/ \mathrm{d}_{3} /, / \int /, / \mathrm{r} /$ and the liquid $/ \mathrm{s} /$, which were taken as examples of merging and substitution pronunciation problems.

\section{Factors influencing pronunciation}

Tritch (2016) suggested that teachers should pay attention to key factors that influence pronunciation in order to help the learners overcome pronunciation problems.

Age

Age has been an issue long analyzed in first and second language acquisition. In this discussion, the critical period hypothesis for language acquisition was a concept proposed by Lenneberg (1967) that established that children learn a language and the sounds of the words accurately by imitation of the sounds they hear. However, when dealing with children older than twelve or adults, this "learning through imitation" ability seems to be absent. Therefore, Shoebottom (2012) suggests that teachers should take a different route by taking advantage of adults' ability to analyze concepts and understand easily the explanations on how sounds are produced, which could motivate them to improve their pronunciation.

\section{Motivations}

Students learn and improve more in any area if they are motivated. Celce-Murcia, Brinton and Goodwin ( 2010) identify three goals or desires that motivate students in language learning:

1.Learners want to be accepted into a group (integrative motivation)

2. Learners want to be accepted as real members of the group, not like "outsiders" (assimilative motivation)

3. Learners need the language to reach a goal (instrumental motivation)

With this knowledge, the teacher's job is to identify which of these goals is the student's primary goal, and to use that knowledge to motivate students to improve their pronunciation (p.21).

\section{Quantity and quality of Teaching and Methods}

The kind of teaching and model of pronunciation that students have been exposed to also play an important role in pronunciation. In this sense, Tritch (2016) mentions that the amount of practice students have had and the variety of activities- not just "repeat after me" repetitionmake a strong difference in the adequacy of pronunciation. Therefore, it is important for teachers to provide an accurate model and several different opportunities to practice pronunciation.

\section{Exposure to the Target Language}


The amount of English the learners hear is also another factor that clearly affects pronunciation. According to Tritch (2016), learners who are taking English as a second language have a better chance to improve their pronunciation than those who are taking English as a foreign language.

\section{Influence of the learner's L1}

The students' first language or mother tongue can have a positive or negative influence on the pronunciation of the language they are trying to learn. If the sounds in both languages are very similar, the influence could be positive, but when the sounds they are trying to produce are not part of their L1 or are used in a different way, negative interference occurs (Tritch 2016).

\section{Problems caused by differences between first language and second language}

According to Tritch (2016), two types of problems occur when learners try to produce unknown sounds.

\section{Merging}

Tritch (2016) established that when learners hear new sounds or can tell the difference between two sounds, they tend to interpret the sounds of the new language in terms of the phonemes of their mother tongue. This explains why Spanish speakers add the sound of the vowel "e" /3/ to words that start with the liquid /s/ and they pronounce /estudənt/ instead of /'stiu:dənt/. Tritch (2016) observed the fact that such students are not able to perceive the difference between /estudənt/ and /'stiu:dənt/, and defined the problem as "merging" when the interpretation of new sounds via the phonemes of the mother tongue leads to pronunciation mistakes.

\section{Substitution}

Tritch (2016) notes that another common error for learners is to substitute a sound that doesn't exist in their mother tongue with a sound that is somewhat similar and familiar for them. For example the phoneme /dz/ does not exist in Spanish, so students substitute it by the /j/ phoneme that their brain recognizes. Therefore, learners pronounce the word "jungle" as /jungle/ instead of /'dz^ygəl/ or "general" as /jeneral/ instead of/dzenrəl/. Likewise, if the learners are not aware of the difference between the English /r/ and the Spanish /řr/, they simply substitute the sounds and pronounce "ready" as/ředi/ and not /'redi/, adding a tongue vibration that is part of the Spanish $/ \check{\mathrm{r}} /$ articulation.

Celce-Murcia, Brinton and Goodwin (1996) also analysed how the mother tongue interferes in the process of learning a new language and established that the pronunciation problems mentioned above are caused by native language interference or language transfer, two concepts that parallel Tritch's (2016) ideas of merging and substitution.

\section{The most difficult sounds for spanish learners}


Earlier, we mentioned that pronunciation problems can occur when the learners use the sounds of their L1 to produce some desired sound in the language they are learning. If we compare English and Spanish, it is clear that these two languages share many similar sounds. Nevertheless, there are also sounds that are unique to each language. According to Malo (2014), there are 20 vowel phonemes in English, while Spanish has only 5 vowel phonemes. Regarding consonants, English also has more consonant phonemes than Spanish. This causes merging or substitution pronunciation problems for learners that are unable to perceive the new sounds. As Tritch (2016) mentioned, learners will often try to make the desired English sounds match the Spanish sounds they know that are closer in pronunciation.

For teachers, knowing which target language vowels and phonemes are not part of the existing phonological system of the learners could help with the development of strategies to help students overcome the problems they face when dealing with the unknown sounds. The following chart illustrates which phonemes are not part of the Spanish phonological system. Three of them have been analyzed in this paper as examples of substitution mistakes. In the case of the liquid /s/, this sound was chosen for analysis because it is one of the most common merging mistakes for students to make.

Table 1: Consonant phonemes that are not part of the Spanish phonological system

\begin{tabular}{|c|c|c|c|c|}
\hline Phoneme & Existe en español & Example & Existe en ingles & Example \\
\hline$/ \mathrm{v} /$ & - & & + & Van \\
\hline$/ \int /$ & - & & + & She \\
\hline $\mid 3 /$ & - & & + & Visión \\
\hline$/ \mathbf{h} /$ & |- & & + & $\mathrm{He}$ \\
\hline / dz/ & - & & + & Jack \\
\hline$/ \mathbf{r} /$ & + & Carro & - & \\
\hline / ð/ & Alófono de /d/ & Nada & + & They \\
\hline$/ \theta /$, & - & & + & Three \\
\hline
\end{tabular}

Source: modified from (Garcia, 2015)

\section{Approaches to teach pronunciation}

In the process of teaching and learning pronunciation, it is necessary to discuss different approaches that have been developed to deal with this issue. For instance, the bottom-up approach and the top-down approach proposed by Dalton \& Seidlhofer (1994) have great acceptability in the field. The bottomBotton-up approach means that the students will learn the pronunciation of inividual phonemes first, and later they will develop their intonation. This means that teaching the segmental features could be adequate for developing good pronunciation because later on, the suprasegmentals might develop themselves (p.70). On the other hand, the top-down approach deals with patterns of intonation first, and then if it is necessary, the individual phonemes are taught.

Two more approaches that deal with pronunciation are the intuitive-imitative approach and the analytic-linguistic aproach. According to Celce-Murcia, Brinton and Goodwin (1996), the intuitive-imitative approach deals with the ability of the learner to reproduce sounds without any explicit information. Similar to how children learn languages, learners simply reproduce sounds by imitation. In contrast, the analytic-linguistic approach provides the learners with all the possible tools and explicit information about the phonetic alphabet, articulatory descriptions, 
a chart of the vocal apparatus, and more (p.2). This approach provides all the necessary tools for students to produce the different sounds in a conscious way.

Tritch (2016) posited that adults had developed a phonological filter that allows them to identify the sound of their mother tongue, but that also "filters out" the unfamiliar sounds of foreign languages. Therefore, adult learners need to consciously "learn to hear again", meaning that they need to be aware that unfamiliar sounds are part of their target language, and require practice in order to perfect their pronunciation. Tritch's (2016) ideas on how to teach pronunciation to adults agrees with the analytic-linguistic approach .

\section{Phonological awareness}

Russell's (YEAR) idea that students are literally unable to hear strange or new sounds leads us to the concept of phonological awareness. According to Gillon (2004), phonological awareness involves the detection and manipulation of sounds at three levels of sound structure: (1) syllables, (2) onsets and rimes, and (3) phonemes. This author also established that the learner performing different phonemes must be aware of the units of sound in order to perform the operation properly. Tritch (2016) goes further in suggesting that learners should know how to move their mouth in order to make the new sound, including where to place the tongue and how to shape the lips. Learners should know exactly what they physically must do in order to produce similar sounds. In this sense, "phonological awareness is an individual's awareness of the phonological structure, or sound structure, of words" (Gillon, 2004). As we can see, developing phonological awareness can help learners to overcome pronunciation problems.

Fromkim (2011) argues that the phonics similarity criterion reflects the ways in which allophones function together and the kinds of generalizations that children or students can make. Her studies reflect that one of the reasons students make pronunciation mistakes is the overgeneralization of sounds due to the lack of phonological awareness. It is clear that for teachers, the process of teaching the sounds that do not exist in the students` mother tongue is a necessity and should be part of the syllabus.

The question now is, "how should ESL/EFL teachers teach pronunciation?" Authors like Derwing \& Munro (2005), Blanco \& Carrillo (2001), and Tritch (2016) have suggested using explicit and analytical phonology to overcome phonological deficits. These researchers suggest that training in the perception and articulation of L2 sounds can help learners to form new phonological categories. The activities presented below aim to help learners develop awareness of unfamiliar sounds and provide them a chance to practice the new sounds.

\section{Some suggestions to teach the $/ \int /, / d_{3} /, /$ r/ or liquid $/ \mathrm{s} /$ phonemes}

There are different techniques that teachers can use to teach pronunciation. Malo (2014) mentions that knowing how to articulate the sounds, constant repetition through drills, and understanding of phonemes are excellent tools to teach pronunciation.

Fromkim (2011) defines the phonemes as "a contrastive phonological segment whose phonetic realizations are predictable by rule" (p. 556). Understanding and identifying the exact 
place of realization or articulation helps in this process of learning pronunciation. Therefore, it could be a good idea to use pictures of articulatory phonetics. For instance, students might benefit from understanding that the 'sh sound' $/ \boldsymbol{J} /$ is voiceless palatal and fricative, and that to produce it, air is forced between a wide groove in the center of the front of the tongue and the back of the tooth ridge (Pronuncian.com, 2016). This might sound complicated, but it may be easier to understand this process by showing students the picture of the articulatory phoneme:

\section{The / $\int /$ sound}

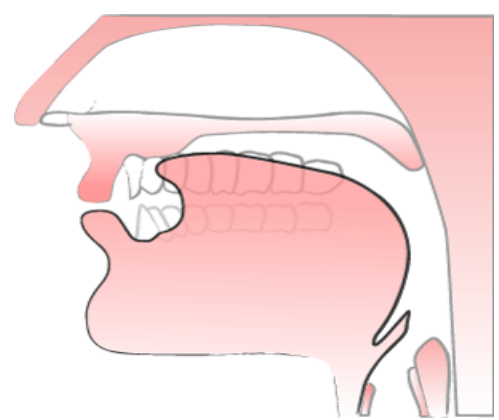

Source: (Pronuncian.com, 2016)

When teaching students how to produce the different phonemes, it is important not to confuse students by telling them what a glottis, larynx, alveolar ridge or any of the vocal tract elements are. As Macháčková, Bc, (2012) suggested, it could be better to use phonology as a tool to help students associate the phoneme with the sound, produce the sounds, and make the process of learning simpler and easier to remember. Tritch (2016) suggested teachers to allow students to see the shape of the tongue, the exact position of the mouth and teeth, and to make them notice how the air goes through the mouth and as they practice the sounds.

Another useful activity to help the learners become aware of the different speech sounds are the "minimal pairs". Teachers ask students to analyze pairs of words that sound similar (e.g., shop and chop, thin and tin, match and mash.) The difference between these words is just one phoneme, and in phonological terms, these kinds of words that differ only in one sound are called minimal pairs. Below is an example of an activity developed with minimal pairs.

Instructions: listen to the teacher reading the words below. Circle the word you hear. Each word will be repeated twice.

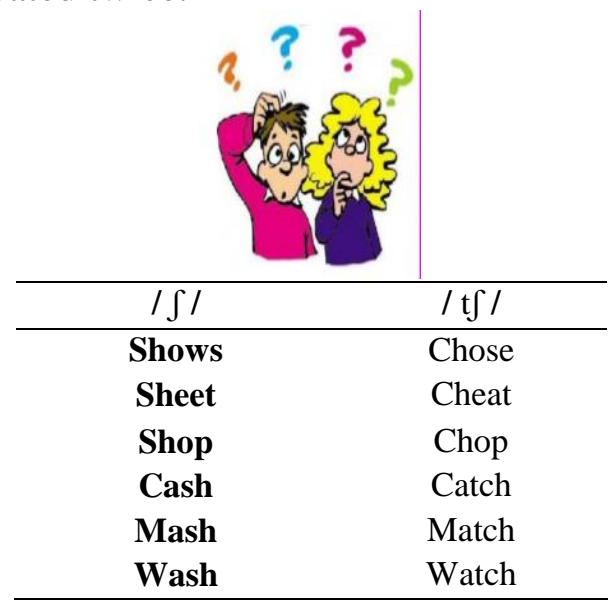




\begin{tabular}{cc}
\hline Wish & Witch \\
$/ \int /$ & $/ d$ J $/$ \\
Shop & Job \\
sheep & Jeep \\
share & Jared \\
shore & George \\
\hline \multicolumn{2}{c}{ Source: authors }
\end{tabular}

To help students become aware of the sound and place of articulation of the / $/$ phoneme for shop, teachers should tell students that "sh" is represented with the phoneme $/ \int /$, but that it is also possible to have this sound with the combinations "t-i" or "c-i", as in the words "national" or "official". Most importantly, teachers should give students the chance to practice each sound for at least one week. A suggestion to do this is by using tongue twisters as warmups at the beginning of each class.

Here are some examples of tongue twisters that can be used to improve the pronunciation of the $/ \mathrm{d} z /, / \int /, / \mathrm{r} /$ and the liquid $/ \mathrm{s} /$ :

\begin{tabular}{|c|c|}
\hline PHONEME & TONGUE TWISTERS \\
\hline$/ \mathbf{d} 3 /$ & Jean, Joan, George and Gerald judged generally. \\
\hline$/ d z /$ & Georgia, put the orange juice into the fridge. \\
\hline & The juice was there for ages because Georgia forgot his orange juice in the fridge. \\
\hline$/ \mathbf{S} /$ & I slit the sheet, the sheet I slit, and on the slitted sheet I sit. \\
\hline Liquid & \\
\hline /s/ & Seven slick, slimy snakes sliding slowly southward. \\
\hline liquid & \\
\hline /s/ & Sammy Smellie smelt a smell of small-coal: Did Sammy Smellie smell a smell of small-coal? \\
\hline liquid & $\begin{array}{l}\text { If Sammy Smellie smelt a smell of small-coal, } \\
\text { Where's the smell of small-coal Sammy Smellie smelt? }\end{array}$ \\
\hline$I \int /$ & $\begin{array}{l}\text { I wish to wish the wish you wish to wish, but if you wish to wish the witch wishes, I won't } \\
\text { wish the wish you wish to wish. }\end{array}$ \\
\hline$/ \int /$ & $\begin{array}{l}\text { Susan shines shoes and socks, socks and shoes shine Susan. She stopped shining shoes and } \\
\text { socks, for shoes and socks shock Susan. }\end{array}$ \\
\hline$/ \mathbf{r} /$ & Jerry's jelly berries taste really rare. \\
\hline$/ \mathbf{r} /$ & Robber the warrior and Roger the worrier were reared wrongly in a rural road. \\
\hline
\end{tabular}

To help students with the $/ \mathrm{d} z /$ phoneme, teachers should make sure they understand that this phoneme occurs with the consonant $\mathrm{J}$ or $\mathrm{G}+\mathrm{e} / \mathrm{I}$, as in the words:

jump, Jill, Joan, juice, July

general, George, fridge, orange, region, originally, engineer

Teachers should then teach the learners how to produce this sound. Teachers can refer to the sound produced in the word "jeep" and show a picture of the vocal tract with the articulatory parts to indicate where students should press their tongue:

The / ds / sound 


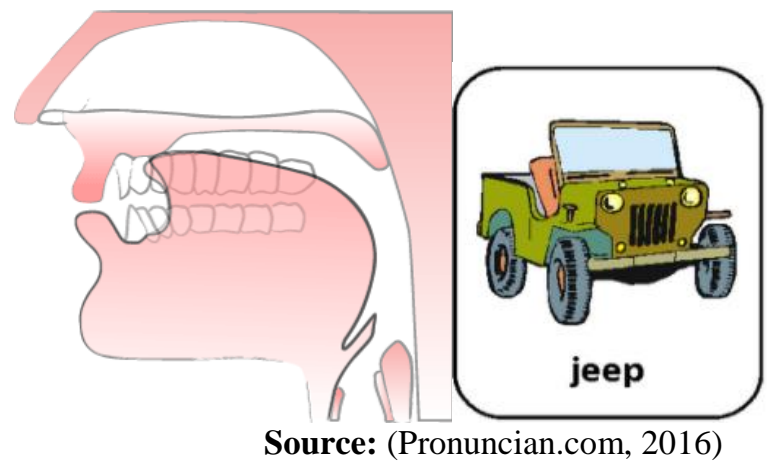

Once the students are aware on how to produce the sound, the practice can be done through the tongue twisters presented above. Tritch (2016) pointed out that learning the pronunciation of unfamiliar sounds is not easy and takes a long time, as well as a lot of practice, until students learn to move the muscles of their mouth in new ways (p.8). Tongue twisters could contribute enormously when teaching pronunciation. As Wells-Smith (2012) said, tongue twister exercises help exercise the muscles in the mouth, enabling clearer pronunciation, clearer speech patterns, and allowing students an easier time pronouncing previously difficult sounds.

Likewise, to teach the $/ \mathrm{r} /$ phoneme, and to help students be aware that the Spanish $/ \check{\mathrm{r}} /$ has some differences in the way of articulation, teachers can repeat the words "carro" and "car" many times. Then, a picture of the vocal tract with the articulatory parts to produce the /r/ phoneme can be shown to help learners realize that the tip of the tongue never touches the tooth ridge, nor makes contact with any other part of the vocal tract. Teachers can help students practice the $/ \mathrm{r} /$ phoneme by having them repeat the tongue twister, "Ray Roger ran across a really risky rough road".

Finally, to develop awareness of the liquid /s/, teachers can ask students to repeat the phoneme $/ 3 /$ and the phoneme /s/ many times and ask the students to listen carefully. Teachers can call their attention to the shape of the mouth while both phonemes are being produced, and ask them to reproduce both sounds and then reduce it down to a short initial "s". Make sure the students notice that in order to produce the phoneme /s/, the lips are held slightly tense and the mouth is almost closed with the tongue touching the side teeth, like in the picture:

\section{The /s/ phoneme}

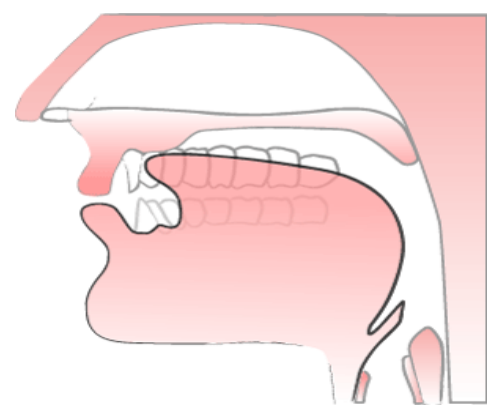

Source: (Pronuncian.com, 2016)

Teachers can tell the learners that the liquid /s/ occurs only in clusters at the beginning of words like in: school, stay, smell, small, stay, student etc. Remind them that the phoneme /s/ 
becomes a pronunciation problem for Spanish students only at the beginning of words. Make students practice the liquid /s/. Here is another activity for the /s/ phoneme done with tongue twisters.

\section{Choose a tongue twister and repeat it three times}

Six slippery snails, slid slowly seaward.

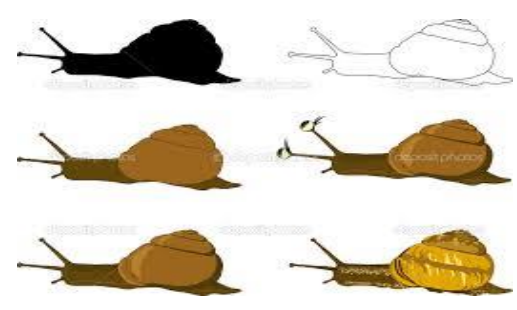

The students brought six sticky skeletons to school

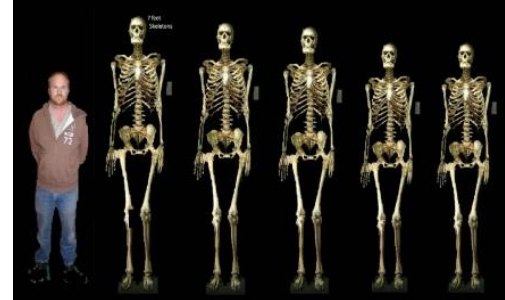

Group work:

Find at least 5 new words that start with the liquid /s/and write them down

1.

2.

3.

4.

5.
Seven slick, slimy snakes sliding slowly southward.

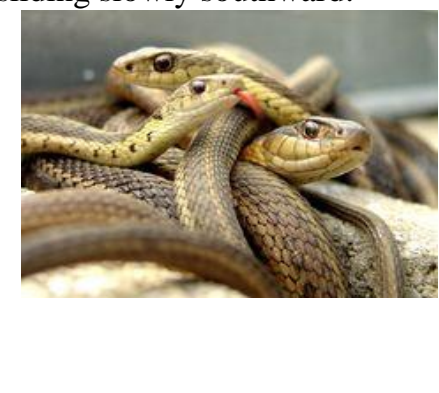

Group work:

Use the words to invent your own tongue twister.

If Sammy Smellie smelt a smell of smallcoal, Smellie smelt?

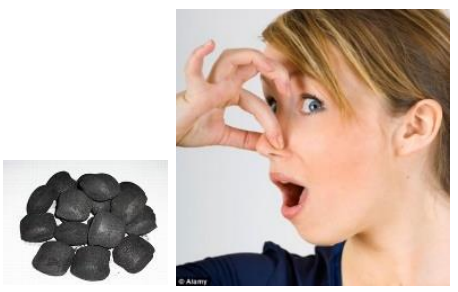

Source: authors

\section{Concluding remarks}

This paper has provided a brief overview of the latest findings about teaching pronunciation. Based on the review of scholarly research conducted to write this paper, it can be concluded that many of the pronunciation problems for L2 learners occur when learners are not aware of new sounds in their target language, thus leading to merging or substitution errors.

Teachers' explicit instruction of phonological sounds can contribute enormously to improve students' pronunciation of unfamiliar sounds. In general terms, we suggest that teachers teach unfamiliar phonemes in an inductive way following the concepts of the analytic-linguistic approach in order to help older students develop phonological awareness. We also demonstrate that the process of learning pronunciation takes time and needs constant repetition, and that the use of tongue twisters as oral exercises can benefit students greatly. Finally, based on these findings, some suggestions were made in terms of other possible activities to help students develop awareness of new sounds and provide practice to achieve accurate pronunciation. 


\section{Bibliography}

Robert, C. (2016, 06). "Spoken English: Flourish you Language”. Retrieved from http://www.sarzaminezaban.com/Data/Articles/Items/2014/6/9788182473485_ Spoken_English.pdf [accessed on Februari 28th 2014]

Blanco, M., \& Carrillo, M. (2001). Analytical training for the teaching of EFL in primary school. Paper presented at the Phonetics Teaching \& Learning. London.

Burns, A., \& Claire, S. (2003). Clearly speaking Pronunciation in action for teachers. Sytney: Macquire University.

Celce-Murcia, M., Brinton, \& Goodwin. (2010). Teaching Pronunciation: A Course bood and Reference Guide. Cambridge: Cambridge University Press.

Celce-Murcia, M., Brinton, D., \& Goodwin, J. (1996). Teaching Pronunciation: A Reference for Teachers of English to Speakers of Other Languages. Cambridge University Press.

Dalton, C., \& Seidlhofer, B. (1994). Pronunciation. Oxford: Oxford University Press.

Derwing, T., \& Munro, M. (2005). Second language accent and pronunciation teaching: A research-based approach. TESOL, 379-397.

Fromkim, V. (2011). An Introduction to language. California: Amy Gibbons.

Garcia, A. (2015). La enseñanza de la pronunciación a estudiantes anglófonos: una propuesta didáctica para la corrección de errores segmentales. Retrieved from http://repositorio.unican.es/xmlui/bitstream/handle/10902/7869/TFM.AGT.pdf?sequence $=1$

Gillon, G. (2004). Phonological awareness: from research to practice. New York: Guilford Press.

Laspra, A. (1992). La formacion inicial de profesorado de Enseñanza Secundaria Area de Inglés. Murcia: Compobell,S.A.

Lenneberg, E. (1967). Biological Foundations of Language. New York: Hohn Wiley.

Macháčková, Bc., E. (2012). Teaching English pronunciation to secondary school students with focus on "th" consonants. Diploma Thesis Masaryk University BRNO.

Malo, A. (2014, septiembre). Tecnicas de enseñanza de la pronunciación del Inglés a estudiantes del primer ciclo de educación primaria. Fonemas de especial dificultad para los hispano hablantes. Retrieved from https://zaguan.unizar.es/record/16621/files/TAZ-TFG-20141890.pdf

Marginson, S., \& van der Wende, M. (2006, September 26). Globalisation and. Retrieved from https://www.oecd.org/edu/research/37552729.pdf 
Pronuncian.com. (2016, 06 05). Retrieved from http://pronuncian.com/sounds

Ramelan. (1994). Ramelan. 1994. English phonetics (5th Ed). Semarang: UPT UNESS PRESS. emarang, Semarang: UPT UNESS PRESS.

Russell, O. (2016). Pronunciation of the Spanish "R". The Modern Language Journal, Vol. 3, No. $4,174$.

Shoebottom, P. (2012). The Factors that Influence the acquisition of a second language. Retrieved from A Guide to learning English : http://esl.fis.edu/teachers/suppport/factors.htm/

Sobkowiak, W. (2016, 06 05). On Tongue Twisters. Retrieved from file://C:/Users/usuario/Documents/1MAESTRIA/17/tongue\%20twisters1.pd

Stuckey, K. (2016, 06 12). Tongue Twisters as a Therapy Tool. Retrieved from www.sn.schule.de/ msweixdorf/dokumente/tongue_twisters.pdf

Tritch , M. (2016). Beyond Repeat After Me. TESOL Press.

Valenzuela Manzanares, J. (2002). Lingüística contrastiva inglés-español: Una vision general. Retrieved from Universidad de Murcia: http://www.um.es/lincoing/jv/2002\%20Contrastivo\%20Carabela.pdf

Walter, E. (1995). Cambridge Advance Learner's Dictionary. Cambridge: Cambridge University Press.

Wells-Smith. (2012, 06 5). The benefits of Tongue Twisters in Speech Therapy. Retrieved from http://www.teachingenglish.org.uk/blogs/admin/tongue-twisters-1 